\title{
Identification of Excretory Secretory (ES) Liquid Antigen Protein Fasciola gigantica with Polyethilen Glycol (PEG) Separation
}

\author{
Yendri Junaidii ${ }^{1,}$, Ima Malawati ${ }^{1}$, Made Sriasih $^{2}$ \\ ${ }^{1}$ Postgraduate Program of the Faculty of Animal Science, Universitas Gadjah Mada, \\ Jalan Fauna No. 3 Bulaksumur, Yogyakarta 55281, Indonesia \\ ${ }^{2}$ Laboratory of Microbiology and Biotechnology, Faculty of Animal Science, \\ Mataram University, Jalan Majapahit 62, Mataram, Nusa Tenggara Barat 83125, \\ Indonesia
}

\begin{abstract}
Fasciola gigantica diagnosis usually performed by detection of worm eggs presence in the feces, but this conventional method has many disadvantages. Early diagnosis (early detection) cannot be performed in conventional methods because the worms in the host's body began to lay eggs at the age of 8-12 weeks of patency. The current detection method that is based on antibody-antigen reactions using excreted/secreted (ES) liquid by adult $F$. gigantica, is believed to be used for the early detection of fasciolosis. This study aimed to characterize the antigenic components of F. gigantica extretory/secretory products that could be used as a vaccine candidate development for early fasciolosis diagnostics. ES products were separated by PEG4000 at various concentrations $(8 \%, 16 \%, 24 \%)$, then precipitates (pellets) obtained were dialyzed and characterized using SDS-PAGE and Western blotting. Results from SDSPAGE showed that there were 18 proteins bands with 7-70 kDa molecular weights. Western blotting on pellets derived from PEG separation at various concentrations affirmed that the proteins of 50, 25 and $20 \mathrm{kDa}$ were antigenic at 8\% PEG concentration, the $25 \mathrm{kDa}$ and $50 \mathrm{kDa}$ were antigenic at $16 \%$ PEG concentrations and the $25 \mathrm{kDa}$ was antigenic at $25 \%$ PEG concentration.
\end{abstract}

Keywords: Antigenic, diagnostic, ES liquid, F. gigantica, fasciolosis, PEG4000

\section{Introduction}

Fasciola spp. infection mainly by $F$. gigantica causing weight loss, lame growth and low endurance and damage the liver and bile as well (Mitchell, 2007). The prevalence of liver flukes by F. gigantica in Indonesia reached 90\% (Abidin, 2002). With high prevalence of the disease, the loss in Indonesia reached \$107 million/year (Spithill et al., 1999). In addition to material losses by zoonosis, an estimated 2.4 to 17 million people around the world suffer from fasciolosis including Asia (WHO, 2009).

According to Estuningsih et al. (2009), attempts to suppress economic loss and

\footnotetext{
*Corresponding author:

Yendri Junaidi

Faculty of Animal Science, Universitas Gadjah Mada, Jalan Fauna No. 3 Bulaksumur, Yogyakarta 55281, Indonesia

E-mail: junaidiyendri@yahoo.co.id
}

morbidity due to worm infections only succeed through a control program that is based on early diagnosis. With early diagnosis, the presence of worms in the body which could cause pathological changes can be prevented. Diagnosis of fasciolosis generally done with conventional enforcement, which is based on the examination of worm eggs in feces. However, this method has the disadvantage of not being able to detect the infection $F$. gigantica during prepaten (8-10 weeks of infection), as well as the low sensitivity.

This shortage fosters the development of immune diagnosis methods of fasciolosis especially $F$. gigantica in order to get faster diagnosis results and more accurate among others by serological methods. Currently, serology inspection of $F$. gigantica is based on the detection of antibodies to the antigen contained in the liquid worm excretory secretory (ES). Anonymous (2011) reported that ES is a protective antigen that can trigger 
a host immune response definitive. ES antigens have properties that could be recognized by the immune response system (Bird, 1991; Chowdhuly and Tada, 1994). Sahebab et al. (1999) reported that the presence of liquid ES is an indication of alive and active worm infection. To produce a necessary protein, ES fluid separation process to other components that are excreted by the worm must be done.

ES liquid protein separation could be done by using protein solvents like polyethilen glycol (PEG). Harris (1992) reported that PEG is a simple molecule with a linear or branched molecular structure. PEG with 700-900 molecular weights are semi solid and PEG with 900-1000 molecular weights or more are solid at room temperature. PEG with molecular weight $<1000$ are viscous, colorless liquid. While PEG with molecular weight $>$ 1000 are candles and white solid form. The number of ethylene glycol determine molecular weight PEG produced. PEG is commonly used for trait selection agent resistance gene is a molecular weight PEG, 4000 and 6000 (Yuliana, 2010).

$\mathrm{Xi}$ et al. (2006) reported that the use of PEG has the advantage as a solvent because it can precipitate protein reagent of good enough for purification of proteins from a variety of sources. In addition, according to Dewi et al. (2012) protein precipitation with PEG does not affect the subsequent purification steps. Based on this study, experiment was conducted to detect the presence of proteins making up liquid separation ES F. gigantica results with different concentrations of PEG, and selecting proteins with antigenic/immunogenic.

\section{Materials and Methods}

\section{Isolation of fluid excretory secretory (ES)}

Adult heartworms F. gigantica is collected and then put in a glass beaker containing $10 \mathrm{~mL}$ Phosphate Buffer Saline (PBS), and stand for $20 \mathrm{~min}$. The regurgitant first discharged, then replaced with new PBS $10 \mathrm{~mL}$, done three times. Adult worms were incubated for one night at $37^{\circ} \mathrm{C}$. Fluid containing protein ES centrifuged 2,500 rpm at $4^{\circ} \mathrm{C}$ for $15 \mathrm{~min}$ and filtered with $0.22 \mathrm{~lm}$ filter. Isolation of proteins were performed at $8 \%, 16 \%$, and $24 \%$ PEG concentrations. Then $10 \mathrm{~mL}$ of fluid ES thawed in $5 \mathrm{~mL}$ falcon tube aside into another. PEG is added into the liquid gradually while shaked in the vortex. ES residual fluid is added until the volume reaches $10 \mathrm{~mL}$ or $800 \mathrm{mg} / 10 \mathrm{~mL}$, slowly shaked in vortex for $30 \mathrm{~min}$ and centrifuged at 10,000 rpm in temperature of $40^{\circ} \mathrm{C}$ for $5 \mathrm{~min}$. Pellet allowed to remain inside the tube (fraction I). The same process carried out three times for fractions II, and fractions III.

\section{Dialysis of protein excretory secretory (ES)}

Samples (supernatant 8\%, 16\%, 18\% and pellets $8 \%, 6 \%, 24 \%$ and final supernatant) were dialyzed using PBS $(87.2 \mathrm{~g} \mathrm{NaCl}$, $\mathrm{Na}_{2} \mathrm{HPO}_{412} \mathrm{H}_{2} \mathrm{O} 392.2 \mathrm{~g}, \mathrm{KH}_{2} \mathrm{PO}_{4} 52.0 \mathrm{~g}$ ) and saline $(174 \mathrm{~g} \mathrm{NaCl})$. Membrane tubing with a cut of 11,000 dalton prepared and dialyzed for 2-3 hours at $4^{\circ} \mathrm{C}$ for each sample.

\section{Characterization of protein ES with SDS- PAGE}

Gel preparation begins with adhering two plates of glass by the separator. Then used as a mold gel (mini slab gel). Resolving gel pre-built with buffer mixture, SDS $10 \%$, acrylamide, TEMED and distilled water. The mixture was put in a mini slab gel, the part that is not filled gel, were filled with distilled water. Then the gel undergo polymerization for $30 \mathrm{~min}$. A layer of water on top of the gel is dried with a tissue. Gel top (stacking gel) with buffer mixture, SDS 10\%, acrylamide, TEMED and distilled water was made after resolving gel was formed. Gel solution up in a pipette and put into a mini slab to reach the top plate. Gel comb installed quickly, then performed the sample preparation with added loading buffer twice and $\mathrm{dH}_{2} \mathrm{O}$. After that, the samples were reheated at $100^{\circ} \mathrm{C}$ for $3 \mathrm{~min}$. The sample was then inserted into the gel wells, and in the running for 2-3 hours. Electrophoresis process was done in electrode buffer (3\% tris, 1:44\% glycine and 0.1\% SDS). Once complete, the gel was washed three times using distilled water. Gel coloring used $\mathrm{CBB}$ then shaked for $1 \mathrm{~h}$. Gel destaining was done by soaking the gel in $150 \mathrm{~mL}$ of acetic acid. 


\section{Analysis of profile protein ES with Western blotting technique}

Samples in the form of pellets, results of each fraction, were prepared. Once ready, SDS-PAGE process began, followed by Western blotting results of SDS-PAGE gel soaked in transfer buffer for $20 \mathrm{~min}$. Then the nitrocellulose membrane (NC) was soaked in $\mathrm{dH}_{2} \mathrm{O}$ for $2 \mathrm{~min}$. Membrane $\mathrm{NC}$ soaked back into the transfer buffer for $10 \mathrm{~min}$. Western blotting stacking material on the tool with the sequence (filter paper, NC membranes, the results of SDS-PAGE gel and the top of the filter paper). Power pac mounted on the machine Western blotting with a voltage of $5 \mathrm{~V}, 0: 10 \mathrm{~A}, 1 \mathrm{~W}$ for $45 \mathrm{~min}$. Removable tool and filter paper attached to the top of the gel removed. NC paper removed and transferred upwards board that has been coated with clear plastic. After the membrane cut to limit the formation of ribbon line desired. Blocking using TBS Tween been added with $5 \%$ skim milk and and stored overnight at $4^{\circ} \mathrm{C}$. Samples were incubated using primary antibodies $\left(1^{\text {st }}\right.$ $\mathrm{Ab}$ ) in the form of skim milk with the addition of bovine serum positive and negative fasciolosis dilution of 1:200 and secondary antibody $\left(2^{\text {nd }} \mathrm{Ab}\right)$ prepared on skim milk with the addition of bovine IgG-HRP dilution of 1:8000 and each incubated for $2 \mathrm{~h}$. The last addition of the substrate, the detection and visualization of the results.

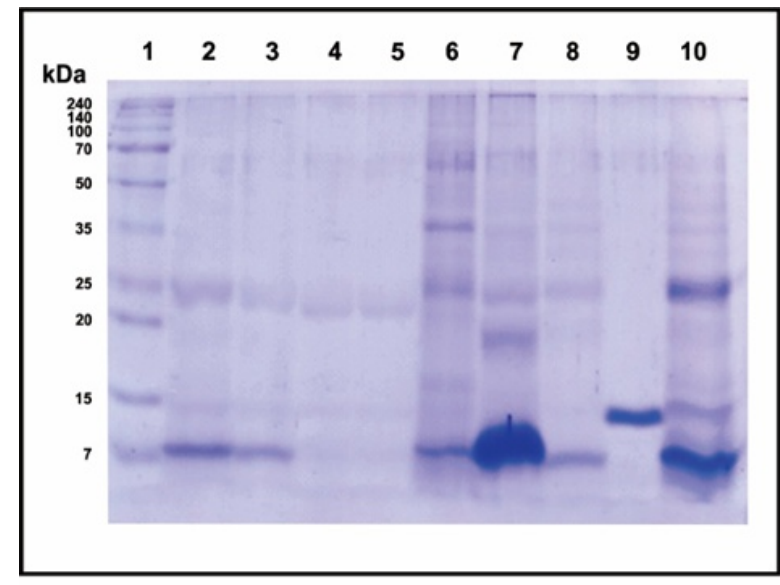

(a)

\section{Results and Discussion}

\section{Profile protein of ES F. gigantica liquid results of the SDS-PAGE}

In this study, ES fluid isolated from worms F. gigantica, then used as a candidate antigen for detecting fasciolosis on livestock, especially cattle. To get the protein constituent, the liquid is separated by using PEG4000 ES with several levels of concentration of $8 \%$ (fraction I), 16\% (fraction II) and 24\% (fraction III). ES result of mixing fluids with varying concentrations of PEG, showed no change in turbidity of the solution and the volume (fraction 1) $10 \mathrm{~mL}$ (fraction II) and $9.5 \mathrm{~mL}$ (fraction III) $8 \mathrm{~mL}$. To know the profile protein molecules and molecular weight of each fraction of the process was then performed SDS-PAGE. Garfin (2003) and Wibowo (2010) mentions that the SDS-PAGE can be used to determine how the protein complex constituent purified sample in the sample. The results of the molecular characterization of proteins using acrylamide gel shown in Figure 1.

ES fluid protein profile of worm $F$. gigantica separation results with varying concentrations of PEG4000 (6\%, 18\% and $24 \%)$ gel electrophoresis using $10 \%$ in Figure 1 shows that the main constituent of protein molecular weight of each fraction ES fluid ranged between $7-70 \mathrm{kDa}$. The results obtained from the count based on the value of RF

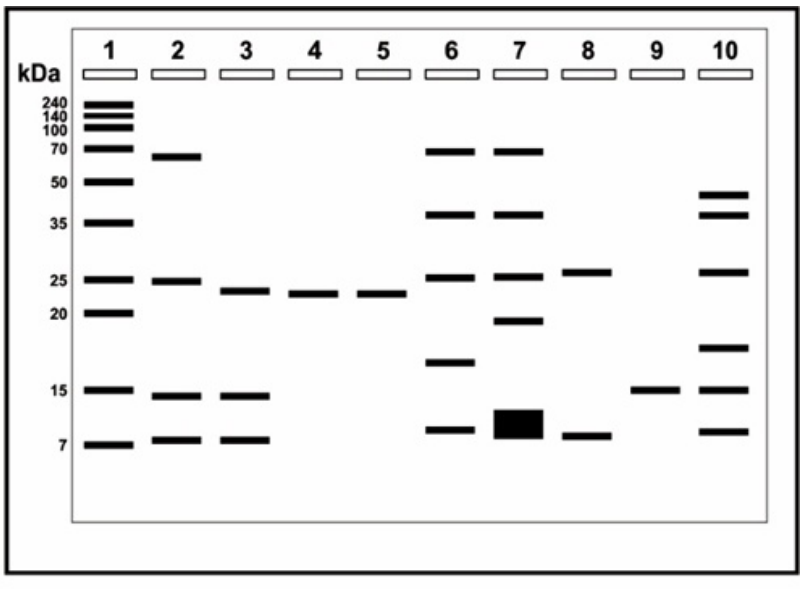

(b)

Figure 1. Results of SDS-PAGE (10\%) protein band profiles and molecular weight protein with ES liquid separation using PEG $_{4000}$. a) SDS-PAGE gel, b) Diagram representative of the gel. 1. marker, 2. profiles supernatant $8 \%$ (fraction I), 3. profiles supernatant of $16 \%$ ( fraction II), 4. profiles supernatant final (fraction IV), 5. profiles supernatant $24 \%$, 6. profiles pellet $8 \%$ (fraction I), 7. profiles pellet $16 \%$ (fraction II), 8 . pellet profile $24 \%$ (fraction III), 9 . the profile lysosim, 10. liquid Pure ES. 
(retardation factor). Results count of RF and $\mathrm{BM}$ Log in marker obtained linear regression line equation $Y=-1,5248 x+19916(R 2=0.9964)$.

Based on the results of a calculation and observation, band profiles of protein from the supernatant and pellet with a PEG concentration of $8 \%, 16 \%$, and $24 \%$ varies from thick to thin. Lastuti et al., (2008) report that thin stained protein bands is a picture of many proteins and also due to genetic differences of protein obtained. Results of protein characterization using SDS-PAGE in this study showed that there were 18 protein bands with molecular weight of $60.58,58.71$, $48.38,40.59,39.36,27.20,26.37,25.57,24.80$, $24.05,19.99,17.67,13.39,11.48,10.79,8.44$, 8.18 and $7.93 \mathrm{kDa}$, with 7-70 kDa molecular weight range. This study was in line with Marcodo (1989), which states that there are 18 protein bands of liquid ES F. gigantica with the molecular weight range 14-96 kDa based on SDS-PAGE. According Meshgi et al. (2007), the test protein characterization ES, there are three common molecular weight in the range of 24, 33 and $42 \mathrm{kDa}$, and in this study all three of these molecules are always visible, so it is said also in line with the results of the study (Mashagi et al., 2007).

Other researchers have reported differences in the number and size of the molecular weight of the liquid constituent ES. Kusnoto (2008) reported that based on the results of ES protein preparation techniques worm Fasciola spp. SDS-PAGE and Western blotting were obtained a few specific proteins include 130, 108, 58, 45.40, 35, 26, 27, 25, 18, 15 and $8 \mathrm{kDa}$. Then Soulsby (1986) also added that the antigen $F$. gigantica of cows has 20 bands pattern with a molecular weight of 14-156 kDa. El-Rahimy (2012) show that there were $13 \mathrm{~F}$. gigantica ES liquid protein based on SDS-PAGE with a molecular weight range of 9.1 to $35.7 \mathrm{kDa}$.

Differences SDS-PAGE results are interpreted is influenced by several factors such as protein solvent used, topography where animals live, breed of cattle, the lifespan of worms that are used, as well as ribbons and long distance gel used. Kusnoto (2013) explains that the calculations using linear regression probable cause relative differences and long distances protein bands and preliminary measurements of gel. Estuningsih and Widjajanti (1998) also mentions that at each level of different ages, worms F. gigantica also excrete proteins and different molecular weights. In the SDS-PAGE result of this research, there are two dominant protein with an indication of the nature that is weighing $8 \mathrm{kDa}$ and $25 \mathrm{kDa}$, because they always appear at each level of fractionation used, either in the pellet and supernatant.

\section{Profile protein antigenic worms F. gigantica result of western blotting}

The process was done by comparing the Western bloting ES antigen in pellet results fractionation with antibodies from cows that positive (+) and negative (-) fasciolosis. Pellet used for Western blotting analysis was based on the results of SDS-PAGE that the protein band pellet that looks more contrast and molecular weight of the protein is more diverse (Figure 2).

Visually lanes 2, 3 and 4 do not show the presence of protein bands due to the use of bovine serum negative (-) fasciolosis, with the sense that the antibodies and antigen binding does not occur. While the antigenic properties of the protein antigen ES treated with bovine serum positive $(+)$ line 5 and 8 show three band of antigenic protein with a molecular weight of $50 \mathrm{kDa}, 25 \mathrm{kDa}$ and 20 $\mathrm{kDa}$. Then line 6 and 9 show the antigenic protein band with a weight range of $50 \mathrm{kDa}$ and $25 \mathrm{kDa}$. Line 7 as well as 10 showed antigenic protein band with a weight range of $25 \mathrm{kDa}$.

The overall data in Figure 2 shows it was found that one protein band weight range $25 \mathrm{kDa}$ was always clearly visible on each lane both on the results of Western blotting and SDS-PAGE, thus indicating that the separation with PEG does not affect the structure of antigenic proteins, it has proven to still recognized protein antigenic/immunogenic $25 \mathrm{kDa}$ even pure on the concentration of PEG $24 \%$.

Data antigenic ES fluid of these results concur with those of Sriasih et al., (2013) that 


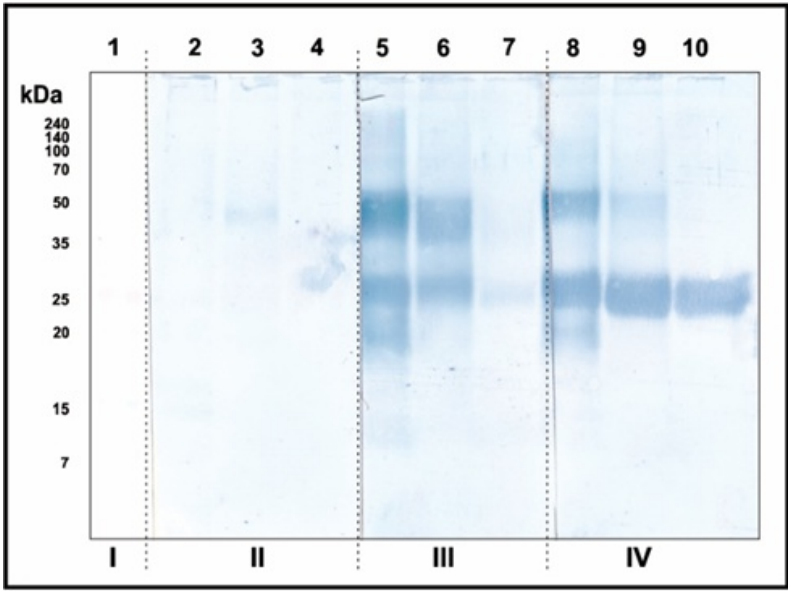

(a)

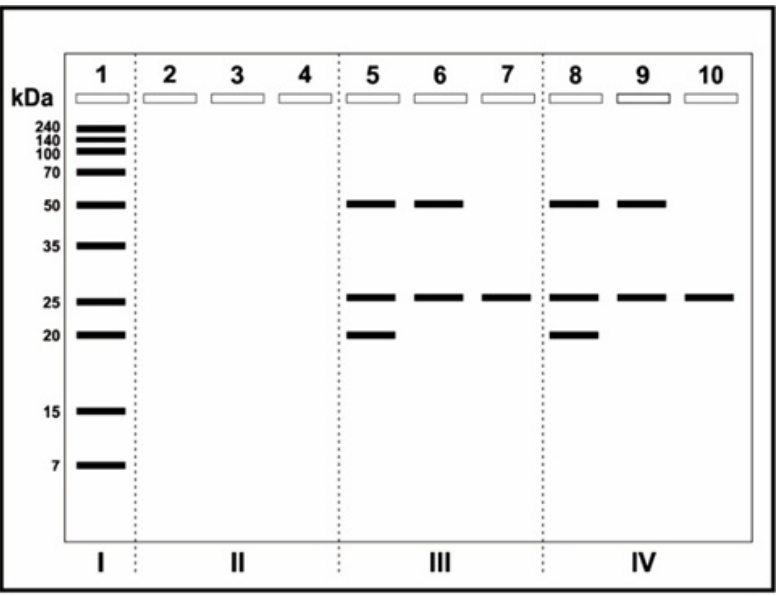

(b)

Figure 2. a) Profile of antigenic protein bands on the NC membrane western blotting results of the three levels of concentration of PEG $(8 \%, 16 \%, 24 \%)$, b) Diagram representative of protein bands on the NC membrane. I (1: Marker), II (2: PEG concentration of 8\%, 3: PEG concentration of 16\%, 4: PEG concentration of 16\%, using bovine serum negative fasciolosis), III (5: PEG concentration of 8\%, 6: PEG concentration of 16\%, 7: PEG concentration 24\%, using bovine serum positive fasciolosis), IV (8: PEG concentration of $8 \%$, 9: PEG concentration of 16\%, 10: PEG concentration of $24 \%$, using bovine serum positive fasciolosis).

the molecular weight antigenic ES liquid worm $F$. gigantica isolates is $7-25 \mathrm{kDa}$. Then according Farghally et al. (2009), a protein component of Fasciola with antigenic has a molecular weight of $29 \mathrm{kDa}$, followed by a $27 \mathrm{kDa}$ and $25 \mathrm{kDa}$. Likewise, the results Mohamed et al. (2004) antigens that are immunoreactive against fasciolosis seruminfected patients is $29 \mathrm{kDa}, 25 \mathrm{kDa}$ and 12 kDa. Rivera-Marrero et al. (1988) also reported that the protein band with a weight of $25 \mathrm{kDa}$ and $30 \mathrm{kDa}$ of fluid F. gigantica ES is a protein with specific properties for acute and chronic fasciolosis in rabbits, cows and sheep. Similar to the results of research Priago (2006) against worms F. gigantica and F. hepatica, the dominant protein profiles appear with a molecular weight of 29.3, 25, and $19 \mathrm{kDa}$.

However, some of the results reported by other researchers such as Estuningsih and Widjajanti (1998) reported that the antigenic properties of the fluid found in the ES-weight proteins $46 \mathrm{kDa}$ and $47 \mathrm{kDa}$. Then Naverrete et al. (1993) reported that ES F. gigantica specific molecule is a molecule with a weight of 23-37 $\mathrm{kDa}$. In addition, the study Sari-Mehmeoglu (2002) also explains the difference, which according to the research results showed that the infection fasciolosis three proteins with antigenic properties which is $36 \mathrm{kDa}, 29 \mathrm{kDa}$ and $17 \mathrm{kDa}$. The differences are likely influenced by several things such as the influence of individual animals, feed and animal life as well as the geographic point solvent used to separate the protein components of ES. Xi et al. (2006) explains that the addition of PEG with various concentrations can purify many kinds of plant protein with a purity specification levels found in the concentration of PEG is higher $(16 \%$ and $24 \%$ ) based on the results of the analysis of 2D gel performed. Dewi et al. (2012) also confirmed that the precipitation of proteins with PEG does not affect the subsequent purification steps. The difference age of worms as research material also affects the pattern of antigenic protein bands (Estuningsih and Widjajati, 1998). Mas-Coma et al. (2005) explains that the geographical location of a live worm can affect the antigen is excreted. Influence of host species against specific antigen immune response can vary (Sobhon et al., 1996; Meshgi et al., 2008). Besides, Farghaly (2009) also showed that differences in the results of some research can be influenced by the method and course of study especially in making and sample preparation.

\section{Conclusions}

The results of SDS-PAGE for characterization of protein band profiles of constituent fluid ES F. gigantica showed 18 
protein band with a molecular weight ranging between 7-70 $\mathrm{kDa}$. The Western blotting of proteins with weight range of 20-50 kDa and one band with a weight of $25 \mathrm{kDa}$ as an indication of the protein with antigenic properties were excellent. ES separation of proteins with PEG did not affect the subsequent purification step for the protein band with a weight of $25 \mathrm{kDa}$ PEG is still seen at higher concentrations even more specific.

\section{References}

Abidin, Z. (2002) Laporan Tahunan Dinas Peternakan Kabupaten Gowa. Dinas Peternakan Kabupaten Gowa. Jawa Barat. Anonymous. (2011) Pengembangan metode ELISA utuk mendeteksi keberadaan koproantigen Fasciola gigantica pada ruminansia: model uji diagnostik untuk human fasciolosis. Bogor: Sekolah Pasca Sarjana IPB.

Astiti, L.G.S., Estuningsih, E., Hartiningrum, D.B., Muliyati, K., and Ichwan (2011) Pemberantasan dan pengendalian penularan fasciolosis pada sapi bali di Pulau Lombok. NTB: Balai Pengkajian Teknologi Pertanian Nusa Teggara Barat.

Chwohury, N., and Tada I. (1994) Helminthology. New Delhi: SpringerVerlag-Norasa Publising House.

Dewi, N.C., Nurhidayati, T., Purwati, K.I. (2012) Pengaruh penambahan PEG (Polyethylen Glicol) terhadap profil protein tembakau (Nicotiana tabacum L. var Prancak 95) pada media in vitro. Surabaya: FMIPA Institut Teknologi Sepuluh November.

El-Rahimy, M. (2012) Evaluation of some Fasciola gigantica antigens as vaccines against fasciolosis in goats. Giza: Department of Internal Medicine and Infectious Diseases, Faculty of Veterinary Medicine. Cairo University.

Estuningsih, S.E., Spithill, T., Raadsma, H., Law, R., Adiwinata, G., Meusen, L., and Piedrafitall, D. 2009. Development and application of a fecal antigen diagnostic sandwich ELISA for estimating prevalence of Fasciola gigantica in cattle in Central Java, Indonesia. J. Parasitol., 95(2), 450-455.

Garfin, D.E. (2013) Gel electrophoresis of proteins. In: Davey J., and Lord, M. (Eds) Essential cell biology vol. 1, chapter 7: cell structure, a practical approach. Oxford: Oxford University Press.

Farghaly, A.M., Nada, S.M., Emam, W.A., Matter, M.A., Mohamed, S.M.A., Sharaf, E.M., and El-Gamal, R.A. 2009. Role of Fast-ELISA and Western Blot in diagnosis of human fasciolosis using crude adult worm and excretory/secretory Fasciola antigen. Int. J. Vet. Sci. Med., 1(2), 55-65.

Guyton, A.C., and Hall, J.E. (2007) Fisiologi kedokteran edisi 11 (Translation of the Textbook of Medical Physology $11^{\text {th }}$ Edition). Jakarta: EGC.

Harris, M.J. (Ed.) (1992) Poly(ethylene glycol) chemistry: biotechnical and biomedical applications. New York: Plenum Press.

Kim, K., Yang, H.J., and Chung, Y.B. 2003. Usefulness of $8 \mathrm{kDa}$ protein of Fasciola hepatica in diagnosis of fasciolosis. The Korean J. Parasitol., 41(2), 121-123.

Kumar, N, Ghosh, S., and Gupta, S.C. 2008. Early detection of Fasciola gigantica infections in buffaloes by enzim linked immunosorbent assay. Parasitol. Res., 103, 141-150.

Kusnoto, Subekti, S., Sudiana, I.K., and Soedarno. 2011. Karakterisasi dan isolasi protein spesifik dari material Ekskretori-Sekretori (ES) Toxocara cati untuk pengembangan diaknostik toxocariasis dengan teknik ELISA. JBP, 13(1), 56-65.

Lastuti, N.D.R., Pasila, A.R., and Nurhayati, T. 2008. Identifikasi profil protein eksresi sekresi cacing Haemonchus contortus dewasa dengan SDS-PAGE. Veterinaria Medika, 1(1), 39-42.

Laula, P.D., Koesdarto, S., and Atik, M,G. (2007) Karakterisasi protein ekskretori sekretori larva stadium kedua dorman terhadap antibodi anti-larva stadium kedua Toxocara canis dengan teknik Western blot. Thesis. Faculty of 
Veterinary Medicine Airlangga University. Surabaya.

Marcodo, R. 1989. Detection of immunocreative peptides of $F$. gigantica with sera from infected subjects by enzyme immunoelectrotransfer. Bol. Chil. Parasitol., 44(3-4), 86-88.

Mas-Coma, S., Valero, M.A., and Bargues, M.D. 2009. Fasciola, lymnaeids, and human fasciolosis with a global overview on disease transmission epidemiology, evolutionary genetics, molecular epidemiology and control. Adv. Parasitol., 69, 41-146.

Meshgi, B., Eslami, A., and Hemmatzadeh, F. 2008. Determination of somatic and excretory-secretory antigens of Fasciola hepatica and Fasciola gigantica using SDS-PAGE. Iranian J. Vet. Res., 9(1), 77-80.

Mitchell, G.B.B. (2007) Liver fluke. In: Aitken, I.D. (Ed.). Disease of sheep $4^{\text {th }}$ ed. London: Blackwell.

Mohamed, M.M., Al-Sherbiny, M.M., Sharaf, A.A., and Elmamlouk, T.H. 2004. Immunological identification of Fasciola hepatica antigens containing major human T-cell and B-cell epitopes. J. Egypt Soc. Parasitol., 34(3), 751-766.

Neverrete, P. A., Yadav, S.C., and Raina, O.K. 1993. Vaccination of buffaloes with Fasciola gigantica recombinant fatty acid binding protein. Parasitol. Res., 97, 129-135.

Priago, M.V., Valero, M.A., Panova, M., and Mas-Coma, S. 2006. Phenotypic comparison of allopatric populations of Fasciola hepatica and Fasciola gigantica from European and African bovines using a computer image analysis system (CIAS). Parasitol. Res., 99., 368-378.

Rivera, M.C.A., Santiago, N., and Hillyer, G.V. 1988. Evaluation of immunodiagnostic antigen in the ES production of Fasciola hepatica. J. Parasitol., 74(4), 646-652.

Shehab, A.Y., Hassan, E.M., Abou, B.L.M., Omar, E.A., Helmy, M.H., ElMorshedy, H.N., and Farag, H.F. 1999.
Detection of circulating e/s antigen in the sera of patients with fascioliasis by ELISA: a tool of serodiagnosis and assessment of cure. Trop. Med. Int. Health, 4, 686-690.

Spithill, F.W. (1999) Fasciola gigantica: epidemiology, control, immunology and molecular biology. In: Fasciolosis. Wallingfort: CAB International Publishing.

Sriasih, M., Depamede, S.N., and Ali, M. (2013) Karakterisasi protein antigenik cairan eksretori sekretori cacing $F$. gigantica isolat lokal dengan teknik Western blotting. Research report. Mataram: Mataram University.

Suryana, A. (2009). Dukungan teknologi penyediaan produk pangan peternakan bermutu, aman dan halal. Jakarta: Agricultural Research and Development Agency.

WHO (Wold Health Organization). (2009) Position paper on food-borne Trematode infections and taeniasis/cysticercisis. Vientiane. Lao People's Democratic Republic.

Wibowo, M.S. (2010) Elektriforesis. Bandung: School of Pharmacy ITB.

Yuliana. (2010) Pengaruh invigorasi menggunakan polyethylene glycol (PEG) 6000 terhadap viabilitas benih tembakau (Nicotiana tabacum). Thesis. Faculty of Science and Technology Islamic State University Maulana Malik Ibrahim. Malang.

Xi, J., Wang, X., Li, S., Zhou, X., Yue, L., Fan, J., and Hao, D. (2006) Polyethylene glycol fractionation improved detection of low-abundant proteins by twodimensional electrophoresis analysis of plant proteome. Phytochemistry, 67(21), 2341-2348.

Zhang, W., Peigne, F., Moreau, E., Chauvin, A., Huang, W. 2005. Comparison of modulation of sheep, mouse, and buffalo lympochocyte responses by Fasciola hepatica and Fasciola gigantica excretory-secretory product. Parasitol. Res., 95(5), 333-338. 